УДК 346.9

DOI https://doi.org/10.32849/2663-5313/2020.6.13

Родіон Поляков, юрист

\title{
МИРОВА УГОДА В ГОСПОДАРСЬКОМУ ПРОЦЕСІ: ПРАВОВА ПРИРОДА ТА СПІВВІДНОШЕННЯ РІЗНОВИДІВ
}

Статтю присвячено мировій угоді в господарсвкому прочесі, а саме правовій природі та співвідношенню ї різновидів. Досліджено такі види мирової угоди, як загальна та спеціальна мирові угоди. Загальна розглядається та затверджується господарським судом за правилами Господарського процесуального кодексу України, спечіальна - мирова угода у справах про банкрутство. Підкреслено, що у зв'язку з набранням законної сили Кодексу Украӥни з проиедур банкрутства, спеиіальний вид мирової угоди припинив своє існування. Автором наголошується, що поняття загальної мирової угоди наразі на законодавчому рівні відсутнє. Разом із тим легальне закріплення поняття мирової угоди в нормах ГПК України сприятиме покращенню правозастосування в иій сфері та зниженню рівня довільного тлумачення ї̈ змісту сторонами.

Наводяться відмінності двох зазначених видів мирової угоди, зокрема щодо їх різної направленості. Аргументується, що загальна мирова угода відноситься до договірного виду угоди, адже в такому випадку вимагається згода кожного кредитора, оскільки така угода стосується виключно прав і обов'язків ї̈ сторін, а отже, наявне вільне волевиявлення та єдність волі і волевиявлення. Щодо спеціального виду мирової угоди, то він є симбіозом процесуального документу з договором. У такому випадку волевиявлення здійснюється шляхом надання згоди комітетом кредиторів, проте саму згоду він може надати тільки за умови згоди більшості кредиторів.

Наголошується, що мирова угода у справі про банкрутство має певну специфіку, оскільки в межах справи про банкрутство відсутній спір, адже борг боржника не викликає жодних заперечень, єдине питання, яке має бути вирішено - це задоволення майнових вимог кредиторів. 3 огляду на це неможливо говорити про вирішення якогось спору шляхом укладення мирової угоди в процедурі банкрутства.

У результаті дослідження автор доходить висновку, що з метою покращення становища боржника варто повернути інститут спечіальної мирової угоди до прочедури банкрутства, який хоча й буде дещо відрізнятись від угоди, що була закріплена в Законі про банкрутство, однак вона має неодмінно відповідати самій сутності процедури банкрутства, складником якої вона виступає.

Ключові слова: мирова угода, господарський процес, господарський суд, справа про банкрутство, банкрутство.

Постановка проблеми. Мирова угода 3 давніх давен виступала особливим способом як вирішення спору між сторонами в рамках позовного провадження, так і способом закінчення провадження у справі про банкрутство.

Донедавна в Україні існувало два види мирової угоди - загальна, передбачена для всіх учасників господарського процесу, та спеціальна, яка використовувалася виключно у справах про банкрутство. 3 моменту набрання законної сили Кодексом України з процедур банкрутства [6] (далі - КЗПБ, Кодекс) спеціальний вид мирової угоди припинив своє існування, що у свою чергу породило немало суперечностей.

Теоретичну основу статті становлять праці таких вчених, як: В. Бондик, Е. Васьковский, А. Дубинчин, О. Подцерковний,
П. Попков, Т. Степанова, Г.Ф. Шершеневич та ін. Разом із тим актуальним залишається дослідження видів мирової угоди в господарському процесі, виявлення їхніх відмінностей, правової природи та специфіки в залежності від виду провадження.

Метою статті $\mathbf{\epsilon}$ аналіз правової природи мирової угоди, характеристика іiї видів, їх співвідношення, а також дослідження доцільності існування двох видів мирової угоди.

Виклад основного матеріалу. 3 метою досягнення ефективних результатів даного дослідження автором розглядаються та виокремлюються такі види мирової угоди:

- загальна - мирова угода, яка укладається за правилами Господарського процесуального кодексу України (далі - ГПК України) [4]; 
- спеціальна - мирова угода у справах про банкрутство.

Насамперед пропонуємо розглянути визначення поняття зазначених видів угод.

Варто підкреслити, що поняття загальної мирової угоди наразі на законодавчому рівні відсутнє. Водночас стаття 192 ГПК України надає можливість сторонам з метою врегулювання спору укласти мирову угоду на підставі взаємних поступок. Така угода має стосуватися лише прав та обов'язків iii сторін. Уклавши мирову угоду, сторони зобов'язуються зробити про це спільну заяву задля повідомлення суду, який має затвердити дану угоду. У результаті постановлення ухвали про затвердження мирової угоди вона підлягає обов'язковому виконанню, оскільки є виконавчим документом.

У своєму дисертаційному дослідженні П. Попков пропонує визначення поняття мирової угоди як укладений шляхом здійснення визначених ГПК України розпорядчих процесуальних дій двохсторонній або багатосторонній процесуальний договір, який здійснюється сторонами господарського процесу та затверджений суддею/суддями господарського суду, Верховного Суду, направлений на припинення господарського спору та закриття провадження у справі 3 метою оперативного врегулювання матеріальних господарських правовідносин [8, с. 3]. Вважаємо, що легальне закріплення поняття мирової угоди в нормах ГПК України сприятиме покращенню правозастосування в цій сфері та зниженню рівня довільного тлумачення її змісту сторонами.

Визначення поняття спеціальної мирової угоди у справі про банкрутство до набрання чинності КЗПБ регламентувалось ч. 1 статті 77 Закону України «Про відновлення платоспроможності боржника або визнання його банкрутом» (далі - Закон про банкрутство) [11]. Так, мирова угода у справі про банкрутство - це домовленість між боржником i кредиторами стосовно відстрочки та/або розстрочки, а також прощення (списання) кредиторами боргів боржника, яка оформляється шляхом укладення угоди між сторонами.

Г.Ф. Шершеневич під мировою угодою у справі про банкрутство розумів затверджену судом угоду між боржником та встановленою в законі більшістю конкурсних кредиторів, спрямовану на визначення взаємних відносин між неспроможним боржником та всіма його кредиторами, з припиненням порушеного конкурсного процесу. При цьому зміст мирової угоди зводився або до розстрочки платежів, або до знижки в платежах [14, с. 439].
3 аналізу наведених нормативних положень щодо мирової угоди можна виділити такі їнні відмінності. Передусім проглядається різна направленість цих двох видів угоди. Так, загальний спрямований на укладення угоди між боржником і його кредитором чи кредиторами, однак за наявності більше одного кредитора кожен кредитор має надати згоду на укладення мирової угоди. Дана особливість пояснюється тим, що мирова угода може стосуватися лише прав та обов'язків її сторін.

Що стосується спеціальної мирової угоди, то в даному випадку сторонами виступають боржник і кредитори в особі комітету кредиторів. При цьому рішення про укладення мирової угоди зі сторони кредиторів приймається більшістю голосів (ч. 3 статті 77 Закону про банкрутство). За наявності ж кредиторів, вимоги яких забезпечені заставою майна боржника, вимагається також окрема згода на укладення мирової угоди кожного з таких кредиторів.

Слід зауважити, що в спеціальній літературі прослідковуються різні погляди на природу мирової угоди. Так, окремі науковці розглядали мирову угоду як договір (Чарльз Лійон-Кан, Луї Рено, Герман Генріх Фіттінг та інші).

Такі російські вчені, як В.С. Белих, О.А. Дубінчин та М.Л. Скуратовський, розглядають мирову угоду як цивільно-правову угоду у вигляді багатостороннього договору між боржником, його кредиторами, а також третіми особами. Обгрунтування договірного характеру мирової угоди, на їхню думку, слід шукати в площині теми щодо примусового укладення договору як обмеження одного 3 трьох проявів принципу свободи договору [1, с. $184 ; 5$, с. 17]. На думку Г.Ф. Шершеневича, договірний погляд $є$ основним $[15$, c. $555-556]$.

Однак німецький юрист Август Зігмунд Шульце вважав, що мирова угода скоріш за все є видом процесуального документа [14, с. 440]. Свою позицію він обгрунтовував тим, що в укладенні договору важливою особливістю є його свобода. Оскільки мирова угода укладається шляхом надання згоди комітетом кредиторів, яка отримується волею більшості під час голосування, отже, свобода договору, а саме волевиявлення та єдність волі та волевиявлення меншості кредиторів відсутні. Більше того, для набрання чинності мировою угодою необхідне затвердження ï судом, у зв'язку з чим така угода є скоріше процесуальним документом, ніж договором, адже примус іiі виконання зумовлюється судовим рішенням, яким затверджується мирова угода, а не самою угодою. 
Заслуговує на увагу позиція Є.В. Васьковського, який вважав, що умови дійсності мирової угоди повинні визначатися відповідно до норм матеріального права, а форма та процесуальні наслідки - згідно з нормами процесуального права [3, с. 457].

Цікавий погляд на природу мирової угоди висловив також німецький юрист Фрідріх Еткер, який у своїй праці «Питання банкрутства» зауважив, що за своєю природою мирова угода є складним юридичним правочином, адже в ньому наявне волевиявлення трьох сторін: боржника, комітету кредиторів та суду [14, с. 441]. На нашу думку, це твердження вдало характеризує даний інститут, оскільки суд має право вибору - затвердити угоду чи ні. Зокрема, відповідно до пунктів 1, 2 ч. 5 статті 192 ГПК України суд постановляє ухвалу про відмову в затвердженні мирової угоди і продовжує судовий розгляд, якщо: 1) умови мирової угоди суперечать закону або порушують права чи охоронювані законом інтереси інших осіб і є невиконуваними; 2) одну зі сторін мирової угоди представляе іiї законний представник, дії якого суперечать інтересам особи, яку він представляє.

При цьому під поняття «закон» у даному випадку підпадає і стаття 203 Цивільного кодексу України [13], яка передбачає умови дійсності правочину. Зокрема, правочин не може суперечити інтересам держави, суспільства та нормам моралі. Саме тому під час затвердження мирової угоди суд має враховувати інтереси держави та суспільства, а отже, певною мірою він стає повноправною стороною складного правочину.

Г.Ф. Шершеневич свого часу висловлювався проти договірної природи мирової угоди, підтримуючи нову теорію мирової угоди як процесуального документа.

Варто звернути увагу на пропозицію Т. Степанової, яка зазначає, що по договірних спорах суд обов'язково повинен проводити співбесіду і пропонувати сторонам укладати мирову угоду. Вчена вказує, що в разі якщо така мирова угода буде укладена до розгляду справи по суті (на першому засіданні), то частина судового збору повинна повертатися [12].

Якщо порівняти вищенаведені поняття двох видів мирової угоди, то можна зробити висновок, що загальна мирова угода скоріш за все відноситься до договірного виду угоди, адже в такому випадку вимагається згода кожного кредитора, оскільки така угода стосується виключно прав і обов'язків її сторін, а отже, наявне вільне волевиявлення та єдність волі і волевиявлення.

Що стосується спеціального виду мирової угоди, то, на нашу думку, він є симбіо- зом процесуального документу з договором. Адже в такому випадку волевиявлення здійснюється шляхом надання згоди комітетом кредиторів, проте саму згоду він може надати тільки за умови згоди більшості кредиторів. Однак надання згоди більшістю кредиторів і згоди боржника ще не означатиме укладення (набрання чинності) мирової угоди, оскільки останнє слово має бути за судом, який у свою чергу може відмовити в iï затвердженні за наявності шкоди меншості кредиторів у результаті злісної домовленості боржника 3 більшістю кредиторів. Тому отримаємо ситуацію, в якій формально $є$ обмеження свободи договору меншості кредиторів, однак за наслідками такого обмеження має слідкувати суд.

Після набрання чинності КЗПБ в Україні залишився лише загальний вид мирової угоди, який передбачений лише нормами ГПК України, за якої важливе вільне волевиявлення кожного кредитора. Якщо така мирова угода буде укладатись у позовному провадженні, то жодної проблеми не буде, оскільки в позовному провадженні в боржника $є$ один чи декілька кредиторів, і отримати згоду кожного 3 них - не така вже й тяжка справа.

Однак якщо застосовувати даний вид угоди у справах про банкрутство, то виникае питання: як отримати згоду декількох сотень, а то й тисячі кредиторів? Тут на допомогу може прийти розуміння поняття «сторони» в контексті статті 1 КЗПБ. Так, сторонами у справі про банкрутство є конкурсні кредитори (представник комітету кредиторів), забезпечені кредитори, боржник (банкрут). Тобто, великою мірою, мирова угода може бути укладена головою комітету кредиторів як представника комітету кредиторів, який у свою чергу представляє конкурсних кредиторів.

Однак за такого тлумачення понять і способів укладення мирової угоди слід розуміти, що голова комітету кредиторів має бути уповноваженим самим комітетом кредиторів на укладення мирової угоди. Оскільки іншого Кодексом не передбачено, то для такого уповноваження щонайменше необхідна згода всіх членів комітету кредиторів, адже інакше буде відсутня єдність волі та волевиявлення, а отже, буде не дотримано вимоги чинного законодавства. Проте слід наголосити на тому, що даний спосіб використання мирової угоди, передбаченої ГПК України, у справі про банкрутство є здебільшого результатом своєрідного тлумачення поняття «сторони», і невідомо, чи запрацює такий механізм на практиці.

Згадавши про практику, не можемо не зупинитись на постанові Північного апеля- 
ційного господарського суду від 11.03.2020 р. у справі № 910/26972/14 [9]. Так, надаючи оцінку можливості укладення у справі про банкрутство за новим КЗПБ мирової угоди, суд зауважив, що КзПБ не містить заборони щодо укладення мирової угоди у справах про банкрутство. На відміну від позовного провадження, в процедурі банкрутства судом не вирішується матеріально-правовий спір, тут має місце погашення встановлених судом грошових вимог кредиторів. Ця обставина як раз і характеризує суб'єктний склад сторін. На відміну від позовного провадження за ГПК України, сторонами мирової угоди, яка має місце в процедурі банкрутства, є: боржник в особі керівника (у процедурі розпорядження майном) або арбітражний керуючий (у процедурі санації та ліквідації), конкурсні кредитори або комітет кредиторів, в особі голови, а також забезпечені кредитори. Предметом мирової угоди є грошові зобов'язання кредиторів, які визнані судом та включені до реєстру вимог кредиторів. Сам факт погашення вимог кредиторів відповідно до реєстру є підставою для закриття справи про банкрутство (ч. 7 статті 41, п. 4 ч. 1 статті 90 КзПБ). Формами погашення (припинення) грошових вимог у відповідності до статті 1 КзПБ $\epsilon$ не лише задоволення вимог, але й припинення зобов'язань унаслідок досягнення домовленості про це. У цій угоді про припинення грошових зобов'язань не виключається можливість застосування всього комплексу інструментарію, який міститься в гл. 50 Цивільного кодексу України «Припинення зобов'язання», в тому числі: відстрочка, розстрочка, прощення (списання), а також відповідно до статті 528 Цивільного кодексу України і виконання зобов'язань третьою особою [9].

Мирова угода у справі про банкрутство має певну специфіку. Справа в тому, що в межах справи про банкрутство відсутній спір, адже борг боржника не викликає жодних заперечень, єдине питання, яке має бути вирішено - це задоволення майнових вимог кредиторів. Тому, на нашу думку, неможливо говорити про вирішення якогось спору шляхом укладення мирової угоди в процедурі банкрутства, оскільки неможливо вирішити те, чого не існує.

Слід зупинитись також на питанні двохсторонніх поступок у мировій угоді. Так, під час укладення мирової угоди в процедурі банкрутства поступки роблять лише кредитори, які надають боржнику розстрочку, відстрочку чи прощення частини боргу задля того, щоб задовольнити свої майнові вимоги, не чекаючи на закінчення процедури. Схожу позицію висловлює В.А. Бондик, який наголошує, що кредитори укладають мирову угоду через існування більшої ймовірності повернення боргів [2, с. 35].

Інші науковці дотримуються позиції, що боржник теж робить поступки в разі відстрочки, адже погоджується розрахуватись із кредиторами протягом певного часу. Так, О.П. Підцерковний вважає, що інститут мирової угоди не може існувати без взаємних поступок сторін, які мають ураховуватися суддями під час вирішення будь-яких господарських справ, зокрема у процедурах банкрутства [7, с. 12].

Однак варто зауважити, що в процедурі банкрутства у боржника є вибір: або пройти всю процедуру і погасити заборгованість, навіть шляхом ліквідації, або домовитись із кредиторами про відстрочку i, таким чином, зберегти власне підприємство та задовольнити їхні вимоги.

Знову ж таки, якщо проаналізувати поняття загальної мирової угоди, то ми бачимо, що вона укладається сторонами 3 метою врегулювання спору шляхом взаємних поступок, а отже, певною мірою суперечить самій сутності мирової угоди у справі про банкрутство.

Однією з відмінностей спеціальної мирової угоди є можливість участі в ній третіх осіб, які не є учасниками справи та мають намір виконати зобов'язання боржника. Завдяки цьому боржник може продовжити своє функціонування із зобов'язанням подальшого розрахунку з даною особою, а кредитори - задовольнити власні майнові інтереси. На жаль, загальний вид мирової угоди такої можливості не передбачає.

Проаналізуємо наслідки укладення загальної та спеціальної мирової угоди. Схожим наслідком $є$ те, що в обох випадках будуть зроблені поступки на користь боржника. Однак якщо спеціальну мирову угоду можна було розірвати та визнати недійсною в судовому порядку і поновити провадження у справі про банкрутство на тій стадії, на якій було затверджено мирову угоду, то в разі загального виду такої можливості немає, адже в результаті затвердження мирової угоди ухвалою суду вона стає виконавчим документом. У разі невиконання даного виду угоди кредитори будуть вимушені звертатись до суду із заявою про відкриття провадження у справі про банкрутство, тим самим починаючи все спочатку. Наразі з цього питання судова практика лише формується. Разом із тим з метою повноти даного дослідження вважаємо за доцільне її розглянути.

Так, у постанові від 18.05.2020 р. у справі № 10/5026/290/2011 [10] Північний 
апеляційний господарський суд, досліджуючи питання можливості звернення до виконання ухвали господарського суду, якою затверджено мирову угоду в процедурі банкрутства, вказав таке. Законодавець передбачав для процедури банкрутства спеціальний порядок настання правових наслідків у випадку невиконання мирової угоди, в тому числі іï розірвання та поновлення провадження у справі про банкрутство. Суд наголосив на тому, що такий порядок існував, поки діяв Закон про банкрутство. 3 набранням чинності КзПБ та у зв'язку з відсутністю в ньому особливого регулювання мирової угоди як правового інструменту в процедурі банкрутства, який закріплювався Законом про банкрутство, а також відсутністю спеціальних норм, які регулюють укладення та виконання мирової угоди у справі про банкрутство, під час вирішення цих питань слід керуватися приписами ГПК України (статті 192, 193). Причому норми ГПК України повинні застосовуватися з урахуванням особливостей КзПБ (частина 6 статті 12 ГПК України). У звязку з тим, що КзПБ не містить спеціальних вимог щодо характеру мирової угоди, то у цій частині також слід керуватися загальними нормами ГПК України (частина 2 статті 193), яка дає мировій угоді, що оформлюється судовим рішенням у вигляді ухвали, характеру виконавчого документу. Це положення стосується як мирових угод, які укладені в силу положень Закону про банкрутство, так і мирових угод, укладених після втрати ним чинності, тобто після набрання законної сили КзПБ [10].

Варто наголосити на тому, що КЗПБ не ліквідував повністю інститут спеціальної мирової угоди, отже, відображення деяких рис можемо знайти в положеннях про санацію. Зокрема, планом санації може передбачатися відстрочення, розстрочення, прощення боргу або його частини (ч. 2 статті 51 КЗПБ). Характерними $є$ також положення про схвалення плану санації більшою половиною кредиторів певного класу (ч. 4 статті 52 КЗПБ). Варто зазначити, що план санації має бути затверджений судом.

Не менш важливим є те, що КЗПБ дозволяє боржнику провести санацію до відкриття провадження у справі про банкрутство і фактично в плані такої санації знаходитимуть відображення положення ч. 2 статті 51 КЗПБ. Дана особливість вказує на те, що законодавець мав бажання ліквідувати спеціальний вид мирової угоди, додавши його елементи до плану санації, а вищенаведений нами спосіб застосування загальної мирової угоди у справі про банкрутство шляхом надання згоди консенсусом членів комітету кредито- рів є тлумаченням законодавства, аніж свідомою волею законодавця.

3 вищевикладеного можна зробити висновок, що спеціальна мирова угода знаходить своє відображення у плані санації в новому КЗПБ, однак така процедура можлива лише до відкриття провадження у справі про банкрутство або на етапі процедури санації. На жаль, під час процедури розпорядження майном, а також під час ліквідації застосувати спеціальну мирову угоду навіть у видозміненому стані (план санації) неможливо.

На нашу думку, дана обставина відіграє негативну роль. По-перше, для країни вигідніше діюче підприємство, адже це сплата податків і робочі місця. По-друге, слід розуміти, що не завжди під час ліквідації кредитори отримають більше, ніж у результаті укладення мирової угоди. По-третє, законодавець не передбачив можливість появи третьої особи, яка б могла виконати зобов'язання боржника, тим самим врятувавши його від ліквідації.

Свого часу в Австрійській Імперії, до складу якої входили окремі українські землі, з'явився новий Конкурсний статут 1868 року, який серед інших нововведень передбачав примусову мирову угоду, яка не містила в собі елементів санації та ухвалювалась зазвичай без значних поступок боржнику, а сам боржник не відновлювався у своїх правах до моменту повного погашення боргів. Дана особливість негативно відбилась на економіці держави та певною мірою сприяла розпаду імперії в 1914 році.

\section{Висновки}

У підсумку слід відзначити, що існування двох видів мирової угоди є логічним явищем, яке зумовлюється специфікою процедури банкрутства. Бажання законодавця ліквідувати спеціальну мирову угоду можна пояснити прагненням спростити процедуру банкрутства, а також стимулювати боржників виконувати власні грошові зобов'язання, адже уникнути цього буде дуже важко або навіть неможливо. Однак, переслідуючи дані цілі, законодавець забуває про безумовні переваги мирової угоди, які будуть неодмінно втрачені.

3 метою покращення становища боржника пропонуємо повернути інститут спеціальної мирової угоди до процедури банкрутства. Можливо, така мирова угода буде дещо відрізнятись від угоди, що була закріплена в Законі про банкрутство, зокрема в частині предмету чи механізму iï укладення. Однак вона має неодмінно відповідати самій сутності процедури банкрутства, складником якої вона виступає. 


\section{Список використаних джерел:}

1. Белых В.С.,Дубинчин А.А., Скуратовский М.Л. Правовые основы несостоятельности (банкротства) : учеб-практ. пособ. / под общей ред. проф. В.С. Якушева. Москва : НОРМА, 2001. 311 с.

2. Бондик В. Особенности функционирования института мирового соглашения в арбитражном процессе. Предпринимательство, хозяйство и право. 2000. № 11. С. 33-35.

3. Васьковский Е.В. Учебник гражданского процесса. Москва, 1914. 571 с

4. Господарський процесуальний кодекс України. URL: https://zakon.rada.gov.ua/laws/ show/1798-12 (дата звернення: 27.05.2020).

5. Дубинчин А. Мировое соглашение в деле о банкротстве: проблемы теории и практики. Хозяйство и право. 2000. № 7. С. 15-24.

6. Кодекс України 3 процедур банкрутства. URL: https://zakon.rada.gov.ua/laws/ show/2597-19 (дата звернення: 27.05.2020).

7. Подцерковный О. Проблемы примирения сторон в арбитражном процессе. Підприємниитво, господарство та право. 2001. № 4. С. 10-14.

8. Попков П.О. Мирова угода в господарському процесі : автореф. дис. ... канд. юрид. наук : 12.00.04. Кривий Ріг, 2019. 17 с.

9. Постанова Північного апеляційного господарського суду від 11.03 .2020 р. у справі № 910/26972/14. URL: http://reyestr.court.gov. ua/Review/88239020 (дата звернення: 27.05.2020).
10. Постанова Північного апеляційного господарського суду від 18.05 .2020 р. у справі № 10/5026/290/2011. URL: http://reyestr. court.gov.ua/Review/89480996 (дата звернення: 30.05.2020)

11. Про відновлення платоспроможності боржника або визнання його банкрутом : Закон України № 2343-XII від 14.05.1992 p. URL: http:// zakon3.rada.gov.ua/laws/show/2343-12 (дата звернення: 27.05.2020)

12. Степанова Т. Процедури примирення в господарському процесуальному законодавстві України: концептуальні засади та перспективи розвитку. Сучасні технології управління підприємством та можливості використання інформачійних систем: стан, проблеми, перспективи : Матеріали сьомої Міжнародної науково-практичної конференції для викладачів, аспірантів та молодих учених, 30-31 березня 2012 р. Одеса, 2012. T. 2. C. 133-137. URL: http://hozpravoodessa.com/index.php/nashi-avtory/18-stepanova$\mathrm{t}-\mathrm{v} / 240$-stepanovaarticle4 (дата звернення: 27.05.2020)

13. Цивільний кодекс України. URL: http:// zakon3.rada.gov.ua/laws/ show/435-15 (дата звернення: 27.05.2020)

14. Шершеневич Г.Ф. Конкурсный процесс. Москва : «Статут», 2000. 477 с.

15. Шершеневич Г.Ф. Курс торгового права. Москва : Бр. Башмаковы, 1912. T. IV. 596 с.

Rodion Poliakov. The amicable agreement in the commercial process: the legal nature and the ratio of its varieties

The article is devoted to the amicable agreement in the commercial process, namely the legal nature and the ratio of its varieties. Such types of amicable agreements as general and special amicable agreements have been researched. The general type is considered and approved by the commercial court according to the rules of the Commercial Procedural Code of Ukraine, the special - amicable agreement in bankruptcy cases. It was emphasized that due to the entry into force of the Bankruptcy Code of Ukraine, a special type of amicable agreement has ceased to exist. The author underscores that the concept of a general amicable agreement is currently absent at the legislative level. At the same time, the legal enshrinement of the concept of amicable agreement in the norms of the Code of Commercial Procedure of Ukraine will help to improve law enforcement in this area and reduce the level of arbitrary interpretation of its content by the parties.

There are differences between the two types of amicable agreement, in particular regarding their different direction. It is argued that a general amicable agreement is a contractual type of agreement, because in this case the consent of each creditor is required, as such an agreement concerns only the rights and obligations of its parties, and therefore there is free will and unity of will and it's expression. As for a special type of amicable agreement, it is a symbiosis of a procedural document with an agreement. In this case, the expression of will is carried out by giving consent by the creditors' committee, but the consent itself can be given only with the consent of the majority of creditors.

It is emphasized that the amicable agreement in the bankruptcy case has a certain specificity, as there is no dispute within the bankruptcy case, because the debtor's debt does not cause any objections, the only issue that needs to be resolved is to satisfy creditors' material claims. Given this, it is impossible to talk about resolving a dispute by concluding an amicable agreement in bankruptcy proceedings.

As a result of the study, author concludes that in order to improve the position of the debtor it is worth to return the institution of a special amicable agreement to the bankruptcy procedure, which, although will be slightly different from the agreement enshrined in the Law of Bankruptcy, but it must correspond to the essence of bankruptcy procedure, the part of which it is.

Key words: amicable agreement, commercial process, commercial court, bankruptcy case, bankruptcy. 